\title{
Effects of some primary and micronutrients on yield of rice (Oryza sativa L.) under Terai situation of West Bengal (India)
}

\section{A. MAHATO AND D. MUKHOPADHYAY}

Received : 18.06.2016; Revised : 31.10.2016; Accepted : 24.11.2016

MEMBERS OF RESEARCH FORUM:

Corresponding author : D. MUKHOPADHYAY,

Department of Soil Science and Agricultural Chemistry, Uttar Banga Krishi Viswavidyalaya, Pundibari COOCHBEHAR (W.B.) INDIA
Co-authors :

A. MAHATO, Department of Soil Science and Agricultural Chemistry, Uttar Banga Krishi Viswavidyalaya, Pundibari, COOCHBEHAR (W.B.) INDIA

\section{Summary}

An experiment was conducted with rice (cv. GOTRA BIDHAN - 1) in soils of Terai alluvial situation of West Bengal during the Rabi season of 2009-2010 to find out the effect of some primary (N-P-K) and micro (Zn-B) nutrients along with organic matter on the variability of yield of rice. The treatments were based on the soil-test based fertilizer recommendation. The average grain and straw yield of rice varied from 2.28 to $4.31 \mathrm{t} \mathrm{ha}^{-1}$ and 3.12 to $4.67 \mathrm{t} \mathrm{ha}^{-1}$, respectively. Maximum grain yield of rice was obtained at the optimum application of the given nutrients. Omission of nutrients from the optimum, caused yield losses from 9.9 to 47.1 per cent. The yield data also revealed that N-P-K-Zn and B were the main limiting factors under the present experimental set-up. The results suggested the need for applying the given nutrients at optimum levels for the successful yield maximization programme.

Key words : Rice, Nutrients, Optimum levels, Yield maximisation

How to cite this article : Mahato, A. and Mukhopadhyay, D. (2016). Effects of some primary and micronutrients on yield of rice (Oryza sativa L.) under Terai situation of West Bengal (India). Asian J. Soil Sci., 11 (2) : 348-352 : DOI : 10.15740/HAS/AJSS/11.2/348-352. 